\title{
ENSAIO
}

\section{A PÓS-COLONIALIDADE E O ARTIFÍCIO DA HISTÓRIA: QUEM FALA EM NOME DOS PASSADOS "INDIANOS"?"}

Dipesh Chakrabart**

É preciso levar o pensamento até o limite. Louis Althusser

I

Recentemente, o projeto pós-colonial dos Subaltern Studies tem sido elogiado porque demonstra, "quiçá pela primeira vez desde a colonização", que "os indianos mostram consistentes signos de reapropriação da capacidade de representar-se a si mesmos [dentro da disciplina da história]" (INDEN, 1986, p. 445). Como historiador membro do grupo de Subaltern Studies, penso que a felicitação contida nesta observação é grata, mas prematura. O propósito deste texto é examinar a problemática da ideia dos "indianos" "representarem-se a si mesmos na história". Por hora, deixemos de lado os complexos problemas de identidade inerentes a uma agência transnacional como os Subaltern Studies, na qual os passaportes e os compromissos carimbados se voltam às distinções de etnicidade de tal maneira que, a alguns, essa identidade parecerá tipicamente pós-moderna. Tenho uma proposição mais perversa para apresentar. No discurso acadêmico da história - quer dizer, a "história" como um discurso produzido no âmbito institucional da universidade - "Europa" continua sendo o sujeito soberano, teórico, de todas as histórias, incluindo as que chamamos "indianas", "chinesas", "quenianas" etc. De uma maneira peculiar, todas estas outras histórias tendem a ser variações de uma narração mestra, que poderia ser chamada de "a história da Europa". Neste sentido, a própria história “indiana” está em uma posição de subalternidade e as posições de sujeito subalterno só podem ser articuladas em nome dessa história da Europa.

\footnotetext{
* Texto originalmente publicado em Representations, n. 37, Special Issue: Imperial Fantasies and Postcolonial Histories. p. 1-2 , Winter 1992. Publicação da versão em português expressamente autorizada pela autor Tradução de Erahsto Felício, professor do Instituto Federal de Educação, Ciência e Tecnologia da Bahia (IFBA), mestre em História Social pela Universidade Federal da Bahia (UFBa). E-mail: erahsto@protonmail.com. Revisão: Gissele Raline Moura.

** Professor da University of Chicago. PhD em História pela Australian National University. Membro fundador do coletivo editorial SubalternStudies e editor fundador do Postcolonial Studies. E-mail: dchakrab@uchicago.edu
} 
O presente texto desenvolverá esta proposição. Antes, porém, permita-me apresentar algumas variações. "Europa" e "Índia" são tratados, aqui, como termos hiperreais, no sentido de que se referem a certas figuras da imaginação cujos referentes geográficos permanecem mais ou menos indeterminados. ${ }^{1}$ Como figuras do imaginário, são suscetíveis de serem debatidas, mas, por ora, tratarei como se fossem categorias dadas, materializadas, como termos opostos que formam um binômio em uma estrutura de dominação e subordinação. Sou consciente de que, ao tratá-los desta maneira, me exponho à acusação de ser nativista, nacionalista, ou, o que é pior, um pecado dentre os pecados, nostálgico. Os acadêmicos de tendência liberal protestariam imediatamente, argumentando que qualquer ideia de uma "Europa" homogênea, indiscutivelmente, se desfaz à menor análise. Isto é certo, porém, assim como o fenômeno do orientalismo não desaparece simplesmente porque alguns de nós alcançamos agora uma consciência crítica do mesmo, da mesma forma, certa versão da "Europa", materializada e celebrada no mundo fenomênico das relações cotidianas de poder como o cenário do nascimento do moderno, continua dominando o discurso da história. A análise não a faz desaparecer.

Que a Europa funcione como um referente silencioso no conhecimento histórico é, de fato, algo óbvio de uma maneira sumariamente ordinária. Há pelo menos dois sintomas cotidianos da subalternidade das histórias não ocidentais, terceiro-mundistas: primeiro, os historiadores do Terceiro Mundo sentem necessidade de se referir às obras de história europeia; por seu turno, os historiadores da Europa não se sentem na obrigação de corresponder. Seja Edward Thompson, Le Roy Ladurie, George Duby, Carlo Ginzburg, Lawrence Stone, Robert Darnton ou Natalie Davis - para citar só alguns nomes ao acaso, todos do mundo contemporâneo -, os "grandes" expoentes e os modelos do ofício do historiador são sempre culturalmente "europeus". "Eles" produzem sua obra em uma relativa ignorância das histórias não ocidentais e isto não parece afetar a qualidade de seu trabalho. Este é um gesto, entretanto, ao qual "nós" não podemos corresponder. Nem sequer podemos nos permitir uma igualdade ou simetria de ignorância neste nível sem correr o risco de parecer "antiquados" ou "superados". O problema, eu poderia acrescentar entre parênteses, não é exclusivo dos historiadores. Uma mostra despreocupada, mas, apesar disso, ostensiva desta "desigualdade de ignorância" nos estudos literários, por exemplo, é o enunciado de Linda Hutcheon, tomado de um texto recente sobre o pós-modernismo e o romance de Salam Rushdie, Filhos da Meia Noite. ${ }^{2}$ Escreve Hutcheon (1989, p. 65):

\footnotetext{
Ainda que Saleem Sinai narre em inglês [...], tanto para escrever história como para escrever ficção, seus intertextos acabam duplicados: por um lado, provém de lendas, filmes e literatura indiana; por outro, de textos do Ocidente, como O Tambor de Hojalata, Tristram Shandy, Cem anos de saudade etc.
}

É interessante observar como o enunciado faz reluzir apenas as referências que provêm do "Ocidente". A autora não tem a obrigação de nomear, com alguma autoridade e especificidade, as

\footnotetext{
${ }^{1}$ Devo a Jean Baudrillard (1983) o termo hiper-real, ainda que o utilize de forma diferente.

2 Filhos da Meia Noite é como Renajit Guha e Saleem Sinai chamaram a geração do grupo de Estudos Subalternos (N.T.).
} 
aludidas fontes "indianas" que "duplicam" a intertextualidade de Rushdie. Esta ignorância, compartilhada e tácita, é parte de um suposto pacto, que torna "fácil" incluir Rushdie nos cursos sobre pós-colonialismo dos departamentos de literatura inglesa.

A ignorância assimétrica não é, simplesmente, questão de "servilismo cultural" (cultural cringe, para deixar falar meu lado australiano) de nossa parte ou da arrogância cultural do historiador europeu. Estes problemas existem, mas podem ser resolvidos de maneira relativamente fácil. Tampouco pretendo menosprezar, longe disso, os avanços dos historiadores que mencionei. Nossas notas bibliográficas aportam copiosos testemunhos das nossas percepções que são derivadas do conhecimento e criatividade desses autores. O domínio da "Europa" como sujeito de todas as histórias é parte de uma condição teórica muito mais profunda e sob sua sombra se produz o conhecimento histórico no Terceiro Mundo. Esta condição se expressa ordinariamente de uma maneira paradoxal. Este paradoxo, que descreverei como o segundo sintoma cotidiano de nossa subalternidade, se refere à natureza mesma dos pronunciamentos da ciência social.

Há várias gerações, filósofos e pensadores que têm dado forma à natureza da ciência social produzem teorias que abarcam toda a humanidade. Como bem sabemos, estas declarações têm sido produzidas em uma situação de ignorância relativa, e por vezes absoluta quando se trata da maior parte da humanidade que vive em culturas não ocidentais. Isto, em si mesmo, não constitui um paradoxo, pois os filósofos europeus mais conscientes de sua própria reflexão sempre justificaram teoricamente esta postura. O paradoxo cotidiano da ciência social do Terceiro Mundo é que, para nós, essas teorias parecem, apesar da ignorância inerente sobre "nós", eminentemente úteis para entender nossas sociedades. Quem permitiu aos modernos sábios europeus desenvolver semelhante clarividência a respeito de sociedades que ignoravam empiricamente? Por que nós, novamente, não podemos corresponder a este gesto?

Existe uma resposta a esta pergunta nos escritos de filósofos que têm lido na história europeia uma enteléquia da razão universal e que consideram a filosofia como a consciência de si mesma da ciência social. Somente a "Europa", segundo o argumento, é teoricamente (quer dizer, no nível das categorias fundamentais que dão forma ao pensamento histórico) conhecível; todas as demais histórias são questões da investigação empírica que encarna um esqueleto teórico que, substancialmente, é "Europa". Existe uma versão deste argumento na conferência de Edmund Husserl proferida em Viena, em 1935. Husserl propôs que a diferença fundamental entre as "filosofias orientais" (mais especificamente, a indiana e a chinesa) e a "ciência greco-europeia" (ou, como acrescentava, "falando em sentido universal: a filosofia") era a capacidade desta de produzir "percepções teóricas absolutas", quer dizer, "theoria" (ciência universal), enquanto aquelas conservavam um caráter "prático-universal" e, segundo ele, "mítico-religioso". As filosofias "prático-universais" se dirigem ao mundo de uma maneira "ingênua" e "direta", enquanto o próprio mundo se apresentava ante a theoria como uma "temática", o 
que tornava possível uma práxis, "cujo fim é elevar a humanidade mediante a razão científica universal” (HUSSERL. 1970, p. 281-285). ${ }^{3}$

Uma proposição epistemológica bastante similar anima o uso que Marx faz de categorias como "burguês" e "pré-burguês" ou "capital" e "pré-capital". O prefixo pré indica, aqui, uma relação tanto cronológica como teórica. O surgimento da sociedade burguesa ou capitalista, como afirma Marx em Grundrisse e em outros lugares, dá lugar, pela primeira vez, a uma história que pode ser compreendida mediante uma categoria filosófica e universal: o "capital". A história se torna, pela primeira vez, teoricamente conhecível. Todas as histórias do passado, a partir de então, serão conhecidas (desde já, teoricamente) do ponto de vista desta categoria, quer dizer, considerando as diferenças em relação a ela. As coisas revelam sua essência categórica somente quando alcançam seu pleno desenvolvimento, ou, como disse Marx naquele famoso aforismo de Grundrisse, "a anatomia humana contém a chave da anatomia do símio.”4

A categoria "capital", como examinei em outro texto, contém o sujeito legal do pensamento da Ilustração (CHAKRABARTY, 1989). Não é de surpreender que Marx tenha dito, no primeiro capítulo tão hegeliano do primeiro volume do Capital, que o segredo do "capital", enquanto categoria, "não pode ser decifrado até que a noção de igualdade humana tenha adquirido a estabilidade de um preconceito popular” (MARX, 1971, v. 1, p. 60). Seguimos com Marx (1973, p. 105):

\begin{abstract}
Inclusive as categorias mais abstratas, a despeito de sua validade - precisamente por seu caráter abstrato - para todas as épocas, são.. mesmo assim... em si mesmas [...] produtos de relações históricas. A sociedade burguesa é a organização da produção, historicamente falando, mais desenvolvida e mais complexa. Por isso as categorias que expressam suas relações e a compreensão de suas estruturas também permitem percepções da estrutura e das relações de produção de todas as formações sociais desaparecidas, a partir de cujas ruínas e elementos se construiu, cujos restos, ainda parcialmente rebeldes, estão presente e suas variações têm importância explícita dentro dela etc. [...] Os indícios de um desenvolvimento superior entre as espécies animais subordinadas [...] só podem ser entendidas depois que já se conhece o maior desenvolvimento que pode ser alcançado. A economia burguesa proporciona assim a chave para a economia antiga.
\end{abstract}

Onde se diz "capital” ou "burguesia", proponho, leia-se "Europa".

\title{
II
}

Nem Marx nem Husserl falavam - pelo menos não nas palavras citadas anteriormente - em um espírito historicista. Entre parênteses, devemos recordar, também, que a visão de Marx sobre a emancipação implicava uma viagem mais além do domínio do capital e, efetivamente, mais além da noção de igualdade jurídica, tão sagrada para o liberalismo. A máxima “a cada um é pago segundo sua habilidade, a cada um segundo sua necessidade" é muito contrária ao princípio de "ao trabalho igual, salário igual". Esta é a razão pela qual Marx continua sendo - em que pese o Muro de Berlim ou as

\footnotetext{
3 Ver também Halbfass (1988, p. 167-168).

4 Ver este argumento em Marx (1973, p. 469-512) e em Marx (1971, v. 3, p. 593-613).
} 
suas ruínas) - um crítico relevante e fundamental tanto para o capitalismo como para o liberalismo e, por isso, central para qualquer projeto pós-colonial e pós-moderno de escrita da história. Não obstante, as declarações metodológicas ou epistemológicas de Marx nem sempre conseguem resistir a leituras historicistas. Sempre houve suficiente ambiguidade nestas declarações para que se tornasse possível o surgimento de narrações históricas “marxistas”. Estas narrações giram em torno do tema da "transição histórica". A maior parte das histórias do Terceiro Mundo são escritas dentro de problemáticas plantadas por esta narração da transição, cujos temas dominantes (frequentemente implícitos) são os do desenvolvimento, da modernização, do capitalismo.

Esta tendência pode ser encontrada em nossos próprios trabalhos, no projeto de Subaltern Studies. Meu livro acerca da história da classe operária teve que lidar com este problema. ${ }^{5}$ O livro Modern India, de Sumit Sarkar (um dos colegas de Subaltern Studies), considerado, com justiça, um dos melhores livros sobre história da Índia dirigidos principalmente para as universidades indianas, abre com o seguinte enunciado:

Os sessenta anos e pouco situados entre a fundação do Congresso Nacional Indiano, em 1885, e a consumação da Independência, em agosto de 1947, viveram, quiçá, a transformação mais grandiosa na longa história do país. Uma transição que de muitas maneiras continua sendo onerosamente incompleta, e é a partir desta ambiguidade central que parece mais apropriado começar nosso estudo (SARKAR, 1985a, p. 1).

Qual categoria de transição ficou “onerosamente incompleta”? Sarkar alude à possibilidade de da existência de várias e nomeia três:

Muitas das aspirações despertadas ao longo da luta nacional ficaram sem se cumprir
- o sonho gandhiano do camponês que chega a ser quem deve ser em Ram-rajya [o
reino do lendário e ideal deus-rei Rama], assim como os ideais da esquerda de fazer
a revolução social. E, como haveria de revelar reiteradamente a história da Índia e
do Paquistão (e de Bangladesh) independentes, inclusive os problemas de uma
completa transformação burguesa e de um afortunado desenvolvimento capitalista
não se resolveram completamente mediante a transação do poder em 1947.
(SARKAR, 1985a, p. 4).

Nem o sonho do camponês de um reino mítico e justo, nem o ideal de esquerda da revolução social[ista], nem uma "completa transformação burguesa" - dentro destas três carências, destas encenações “onerosamente incompletas”, Sarkar localiza a história da Índia moderna.

Também com uma referência similar às "carências" - o "fracasso" de uma história para chegar ao encontro com seu destino (digamos, uma vez mais, um exemplo do "nativo preguiçoso"?) inauguramos nossos projeto de Subaltern Studies:

É o estudo do fracasso histórico da nação para chegar a ser o que deve ser, um fracasso devido à insuficiência da burguesia, assim como da classe trabalhadora para conduzi-la a uma vitória decisiva sobre o colonialismo e a uma revolução burguesademocrática do tipo clássico do século XIX [...] ou [do tipo da] "nova democracia"

5 Ver Chakrabarty (1989), o capítulo 7, em particular. 
- é o estudo deste fracasso o que constitui a problemática central da historiografia da Índia Colonial (GUHA; SPIVAK, 1988, p. 43). ${ }^{6}$

A tendência de ler a história da Índia em termos de carência, de ausência ou como algo incompleto que se traduz em uma "insuficiência” é óbvia nestas citações. Contudo, como alegoria, se trata de uma antiga tendência que remonta à aurora do regime colonial na Índia. Os britânicos conquistaram e representaram a diversidade dos passados “indianos" mediante uma narração homogeneizadora de uma transição desde um período "medieval" até a "modernidade". Os termos mudaram com o tempo. Alguma vez se chamou "despótico" o "medieval", e se chamou o "moderno" de "o respeito à lei". Uma variante posterior seria "feudal-capitalista".

Quando formulada pela primeira vez nas histórias coloniais da Índia, esta narração da transição era uma desembaraçada celebração da capacidade do imperialismo para a violência e a conquista. Para dar só um exemplo entre tantos que nos oferecem, na History of Hindostan, de Alexander Dow, publicada pela primeira vez em três volumes, entre 1770 e 1772, era dedicada ao rei uma candura característica do século XVIII, quando não era necessário um Michel Foucault para revelar a conexão entre violência e conhecimento: “o êxito das forças de sua Majestade", dizia Dow, “abrem as portas do Oriente às investigações dos curiosos". Subtraindo a conexão entre a violência e a modernidade, Dow afirmava:

A nação britânica se converteu na conquistadora de Bengala e deveria estender algo de sua jurisprudência fundamental para assegurar sua conquista [...]. A espada é nossa garantia. É uma conquista absoluta, e assim a considera o mundo. (DOW, 1812-1816, p. cxxxviii).

Esta "jurisprudência fundamental” era o "respeito à lei”, que contrastava, na narração de Dow, com o regime anterior, “arbitrário" e "despótico”. Em nota posterior, Dow explicava que o "despotismo" não se referia a um "governo guiado pelo mero capricho e inconstância", pois sabia suficientemente história para entender que isto não era correto para a Índia. O despotismo era oposto ao governo constitucional inglês. Era um sistema no qual "o poder legislativo, o judicial e o executivo [estavam] encarnados no príncipe.” Este era o passado de falta de liberdades. Com o estabelecimento do poder britânico, o indiano seria convertido num súdito legal, regido por um governo sensível à pressão da propriedade privada (“o fundamento da prosperidade pública”, dizia Dow) e à opinião pública, além de ser supervisionado por um poder judicial no qual “os servidores da justiça deveriam ser independentes de tudo, menos da lei [pois], senão o oficial [o juiz] se converte em um instrumento de opressão nas mãos do despotismo” (DOW, 1812-1816, p. xcv, cl, cxl-cxli).

Durante os séculos XIX e XX, gerações de elites nacionalistas indianas encontraram sua posição de sujeito dentro desta narração da transição que, em várias ocasiões e dependendo da ideologia de cada um, colocou o tapete da "história indiana" entre os dois polos dos conjuntos

\footnotetext{
${ }^{6}$ As palavras citadas são de Guha, mas creio que representam um sentido de responsabilidade compartilhado por todos os membros do grupo de Subaltern Studies.
} 
homólogos de oposições: despótico-constitucional, medieval-moderno, feudal-capitalista. Dentro desta narração compartilhada pela imaginação imperialista e nacionalista, o "indiano" sempre foi uma figura da carência. Dito de outro modo, sempre havia lugar neste relato para personagens que encarnavam, em nome dos nativos, o tema da "insuficiência" ou do "fracasso". A recomendação de Dow sobre o "respeito à lei" para Bengala-Índia era acompanhada da paradoxal garantia (para os britânicos) de que não havia perigo de que semelhante respeito "inculcaria" aos nativos "um espírito de liberdade":

Tornar os nativos da terra de Bengala livres, ultrapassa o poder do pacto político [...]. Sua religião, suas instituições, seus costumes, a disposição mesma de sua mentalidade, os fazem próprios para a obediência passiva. Lhes dar propriedades só os uniria aos nossos interesses de modo mais forte e os faria nossos súditos; ou se a nação britânica prefere esta palavra - mais nossos escravos. (DOW, 1812-1816, p. cxl-cxli)

Não é necessário lembrar que esta seria a pedra fundamental da ideologia imperial durante muitos anos - os nativos tratados como súditos e não cidadãos, pois nunca tiveram capacidade para a cidadania - e, com o tempo, se converteria em uma variedade da própria teoria liberal. ${ }^{7}$ Os nacionalistas se ressentiam disto. Tanto para Rammohun Roy como para Bankimchandra Chattopadhyay, dois dos intelectuais nacionalistas mais proeminentes da Índia do século XIX, o regime britânico era um período necessário de tutela pelo qual os indianos tinham que passar para se preparar precisamente para o que os britânico lhes negavam, mas que exaltavam como o fim de toda a história: a cidadania e o Estado-nação. Em 1951, um indiano "desconhecido" que conseguiu vender sua "escuridão" escreveria esta dedicatória para a história de sua vida:

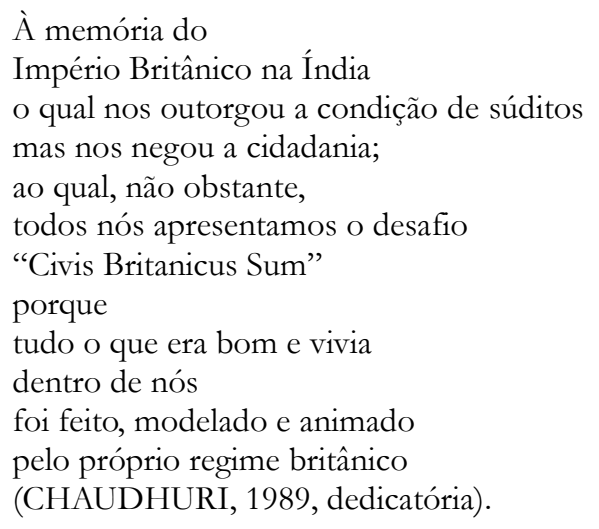

Nas versões nacionalistas desta narração, como mostra Partha Chatterjee (1986), os camponeses e os trabalhadores, as classes subalternas, foram os que carregaram a cruz da "insuficiência", pois, segundo esta versão, eram eles que necessitavam ser educados para sair da ignorância, do provincianismo ou, dependendo de sua preferência, de uma falsa consciência. Hoje, inclusive, a palavra de origem anglo-indiana "comunalism" (comunalismo) se refere àqueles que, presumivelmente, não conseguiram estar à altura dos ideais “seculares" da cidadania.

7 Ver Hobhouse (1964, p. 26-27). 
É inegável que o regime britânico tenha estabelecido as práticas, instituições e discursos do individualismo burguês em terras indianas. As primeiras expressões - quer dizer, antes dos primeiros passos do nacionalismo - deste desejo de ser um "súdito legal" deixam claro que, para os indianos dos anos trinta e quarenta do século XIX, ser um "individuo moderno" era se converter em "europeu”. The Liberary Glener, uma revista da Calcutá colonial, publicou o seguinte poema em 1842, escrito em inglês por um estudante bengali de dezoito anos de idade. O poema se inspirava, aparentemente, na vista das naus que partiam da costa de Bengala "até as gloriosas costas da Inglaterra":

A miúde suspiro como uma triste ave
por deixar esta terra, ainda que seja a minha terra;
seus arroios vestidos de ervas - alegres flores e céus sem nuvens
ainda assim são mais que belos, pouco encanto tem para mim.
Pois tenho sonhado com climas mais brilhantes e livres
onde habita a juventude e a liberdade celestial
onde até os mais humildes se tornam felizes - onde a vista
não se ofende ao ver um homem se inclinar
ao sórdido interesse - são climas onde prospera a ciência,
e o gênio recebe sua justa honraria;
onde o homem vive em toda sua glória de forma mais verdadeira,
e o rosto da natureza é esquisitamente doce:
Para aqueles climas lanço meu impaciente suspiro,
deixem-me viver ali, ali me deixem morrer.

Com seus ecos de Milton e de radicalismo inglês do século XVII, é claro que esta é uma mostra do pasticho colonial. ${ }^{8}$ Michael Madhusudan Dutt, o jovem autor bengali deste poema, finalmente se deu conta da impossibilidade de ser "europeu" e voltou à literatura bengali para se converter em um dos nossos melhores poetas. Os nacionalistas indianos posteriores abandonaram, também, o desprezível desejo de se tornar "europeus". A premissa do pensamento nacionalista era, precisamente, a suposta universalidade do projeto de se converter em indivíduos, supondo que os "direitos individuais" e a "igualdade" abstrata fossem conceitos universais que podiam se fixar em qualquer parte do mundo, e que alguém podia ser "indiano" e "cidadão" ao mesmo tempo. Não demoraremos em analisar algumas das contradições deste projeto.

Muitos dos rituais públicos e privados do individualismo moderno começaram a ser notados na Índia durante o século XIX. É possível ver isto, por exemplo, no súbito florescimento, nesta época, dos quatro gêneros básicos que ajudaram a expressar o ser moderno: a novela, a biografia, a autobiografia e a história. ${ }^{9}$ Juntamente com estes gêneros, chegou a indústria moderna, a tecnologia, a medicina e um sistema legal quase burguês (ainda que colonial) sustentado por um Estado que o nacionalismo haveria de ganhar e fazer seu. A narração da transição que tenho examinado avalizava estas instituições e lhes dava sustentação. Pensar esta narração é pensar estas instituições, em cujo ápice assentava o Estado moderno. ${ }^{10}$ E pensar o moderno ou o Estado-nação era pensar uma história cujo

\footnotetext{
${ }^{8}$ Minha compreensão deste poema foi enriquecida com as conversações com Marjorie Levinson e David Bennett.

${ }^{9}$ Não estou afirmando que todos estes gêneros emergiram necessariamente com o individualismo burguês. Cf. Davis (1988), Davis (1986) e Lejeune (1989, p. 163-184).

${ }^{10}$ Ver o capítulo sobre Nehru em Chatterjee (1986)
} 
sujeito teórico era Europa. Gandhi se deu conta disto desde 1909. Ao se referir às demandas dos nacionalistas indianos, de mais ferrovias, medicina moderna e direito burguês, astutamente afirmou, em seu livro Hind Swaraj, que isto era "fazer inglesa a Índia" ou, segundo suas palavras, ter "um regime inglês sem os ingleses" (GANDHI, 1963, p. 15). Esta "Europa", como mostra o juvenil e ingênuo poema de Michael Madhusudan Dutt, já não era senão uma ficção que o colonizador contou aos colonizados no processo de fabricação da dominação colonial. ${ }^{11}$. A crítica de Gandhi a esta "Europa" está, em muitos aspectos, comprometida com o nacionalismo. Não é minha intenção ver seu texto como um fetiche. Entretanto, seu gesto me parece útil para abordar a problemática de histórias escritas fora da metrópole.

\section{III}

Agora irei abordar, novamente, os temas do "fracasso", da "carência" e da "insuficiência", que, de forma ubíqua, caracterizam o sujeito falante da história "indiana". Como nas práticas do campesino insurgente da Índia colonial, o primeiro passo de um esforço crítico deve surgir de um gesto de inversão (GUHA, 1983). Comecemos por onde a narração da transição termina e leiamos "plenitude" e "criatividade" nos lugares onde essa narração nos pede para ler "carência" e "insuficiência".

Segundo a fábula de sua constituição, os indianos de hoje são todos "cidadãos". A constituição adota uma definição quase classicamente liberal de cidadania. Se o Estado moderno e o indivíduo moderno, o cidadão, não são mais do que dois lados inseparáveis do mesmo fenômeno, como afirma William Connolly em Political Theory and Modernity, então o fim da história, para nós indianos, já está à vista (CONNOLLY, 1989). ${ }^{12}$ Contudo, supõe-se que este indivíduo moderno, cuja vida política e pública é vivida na cidadania, também tem um eu "privado" e interior, que se expõe sem cessar em diários, cartas, autobiografias, novelas e, até mesmo, no que dizem aos psicanalistas. O indivíduo burguês não nasce até que sejam descobertos os prazeres da vida privada. Mas esta é uma categoria muito especial de "vida privada" - de fato, se trata de uma "vida pública" diferenciada, pois a vida privada burguesa, como afirma Jürgen Habermas (1989, p. 49), está “sempre orientada à um público [Publikim]."

A vida pública indiana pode imitar a ficção legal burguesa da cidadania - normalmente esta ficção se encena como uma farsa na Índia -, mas o que existe acerca dessa vida privada burguesa e da sua história? Qualquer um que se proponha a escrever história social "a la francesa" com material indiano se dá conta do quão difícil é esta tarefa. ${ }^{13}$ Não se trata de negar que a forma da vida privada burguesa tenha chegado com a dominação europeia. Desde meados do século XIX, existem novelas, diários, cartas e autobiografias indianas, mas raras vezes esses documentos plasmam retratos de um sujeito interminavelmente interiorizado. Nossas autobiografias são notavelmente "públicas"

\footnotetext{
${ }^{11}$ Cf. Visvanathan (1989, p. 128-141 passim).

${ }^{12}$ Cf, também, Bennett (1990).

${ }^{13}$ Cf. Sarkar (1985b).
} 
(portadoras de construções da vida pública que não são, necessariamente, modernas), quando escritas por homens, e contam a história da família, quando escritas por mulheres. ${ }^{14} \mathrm{Em}$ todo o caso, as autobiografias de estilo confessional são notáveis por sua ausência. O único parágrafo do segundo volume de sua aclamada e premiada autobiografia, no qual Nirad Chaudhuri dedica-se a descrever a experiência de sua noite de bodas, é um exemplo tão bom como qualquer outro e vale a pena citá-lo. Devo explicar que se tratava de um matrimônio arranjado (celebrado em Bengala, em 1932) e que Chaudhuri achava que sua esposa não apreciaria seu recém adquirido, mas proibitivo, passatempo: comprar discos de música clássica ocidental. Nossa leitura de Chaudhuri se vê entorpecida, em parte, por nossa falta de conhecimento da intertextualidade de sua prosa - por exemplo, pode ser que exista um influência da recusa puritana de revelar "demais". Ainda assim, este fragmento continua sendo um eloquente exercício de construção de memória, pois aborda o que Chaudhuri "lembra" e "esquece" de "sua experiência da primeira noite". O autor vela a intimidade com expressões como "tampouco lembro" ou "não sei como foi que" (para não mencionar o muito freudiano "descarregamdo minha consciência”) e este velo autoconstruído, sem dúvida, parte do eu que fala:

Me sentia terrivelmente incomodado ante a perspectiva de conhecer como esposa uma menina que era para mim uma perfeita estranha e quando a trouxeram [...] e a deixaram de pé em frente a mim, não tinha nada para dizer. Só vi um sorriso muito tímido em sua cara e timidamente se aproximou e sentou junto a mim na borda da cama. Não sei como foi que depois disso, nós dois acabamos sobre as almofadas, recostados um ao lado do outro. [Chaudhuri ressalta em uma nota de rodapé: Desde já, totalmente vestidos. Nós os hindus [...] consideramos os extremos - totalmente vestidos e totalmente despidos - gestos de modéstia e tudo o que fica entre eles como grosseiramente sem pudores. Nenhum homem decente quer que sua esposa seja uma allumeuse $\left.{ }^{15}\right]$. Então trocamos as primeiras palavras. Ela pegou um dos meus braços, o apalpou e disse: "como está fraco. Vou cuidar muito bem de você". Não lhe agradeci e tampouco lembro, apesar de ter ouvido as palavras e ter sentido que me tocava. O horrível suspense sobre a música europeia havia despertado de novo em minha cabeça e decidi descarregar minha consciência de uma vez e enfrentar o sacrifício, se fosse necessário, de maneira direta e começar o romance de qualquer maneira que pudesse. Depois de um momento eu lhe perguntei timidamente: "Ouve música europeia?". Negava com a cabeça enquanto dizia: "não". Não obstante me arrisquei de novo e desta vez lhe perguntei: "Já ouviu mencionarem um homem chamado Beethoven?". Respondeu com a cabeça querendo dizer "sim". Isso me tranquilizou, mas não me satisfez por completo. Assim, perguntei mais uma vez: "Podes soletrá-lo?". Então disse: "B, E, E, T, H, O, V, E, N". Me senti animado[...] e terminamos dormindo (CHAUDHURI, 1987, p. 350-351).

O desejo de ser "moderno" clama em cada oração dos dois volumes da autobiografia de Chaudhuri. Seu nome lendário é, agora, símbolo da história cultural do encontro hindu-britânico. Não obstante, nas mil e quinhentas e poucas páginas que escreveu em inglês sobre sua vida, este é a única passagem em que a narração da participação de Chaudhuri na vida pública e nos círculos literários é interrompida para dar lugar a algo que se aproxima do íntimo. Como temos de ler estes textos, esta

\footnotetext{
${ }^{14}$ Por ora, deixarei esta afirmação sem fundamentar, mas espero ter a oportunidade de examiná-la posteriormente. Deveria fechar esta declaração mencionando que se refere, principalmente, às autobiografias publicadas entre 1850 e 1910, uma vez que as mulheres se integram à esfera pública somente no século XX, quando a elaboração de seu eu adquire dimensões diferentes.

15 Termo francês alusivo à mulher que faz anúncios públicos de forma pejorativa ou mediante o uso do próprio corpo (N.T.).
} 
história de um varão indiano self-made, sem igual no zelo pela vida pública de cidadão, e que, contudo, raras vezes, se é que o fez, reproduziu em sua escrita outra cara do cidadão moderno, o ser privado interior que tenta, sem cessar, alcançar o público? público sem o privado? Acaso seria mais um exemplo do "incompleto" da transformação burguesa da Índia?

Estas perguntas foram provocadas pela narração da transição, que situa o indivíduo moderno no fim mesmo da história. Não quero dar à autobiografia de Chaudhuri uma representatividade que não tem. A escrita feminina, como já disse, é diferente e os acadêmicos apenas começaram a explorar o mundo da autobiografia na história da Índia. Mas uma das consequência do imperialismo europeu na Índia foi introduzir o Estado moderno e a ideia da nação com o discurso concomitante de "cidadania". De acordo com a ideia de "direitos do cidadão" (quer dizer, "o respeito à lei"), a figura do indivíduo moderno divide-se nas partes "pública" e "privada" do eu, como o jovem Marx alguma vez assinalou em seu On the Jewish Question (MARX, 1975, p. 215-222). Esses temas subsistem - em uma reação contestatória, de aliança e mestiçagem - com outras narrações do eu e da comunidade, que não consideram o laço entre o Estado e o cidadão como o ápice da construção do social.

Essa afirmação também não será objeto de discussão, mas quero demonstrar que ultrapassa limites. Essas outras construções do eu e da comunidade, ainda que sejam documentáveis, nunca terão o privilégio de prover as meta-narrações ou teleologias (supondo que não pode haver uma narração sem pelo menos uma teleologia implícita) de nossas histórias. Isto porque, em parte, essas narrações amiúde manifestam, por si só, uma consciência anti-histórica; quer dizer, implicam posições de sujeito e configurações da memória que desafiam e sufocam o sujeito que fala em nome da história. A "história" é precisamente o lugar onde a luta continua para se apropriar, em nome do moderno (minha Europa hiperreal), destas outras localizações da memória.

Para ilustrar estas proposições, passarei a examinar agora um fragmento desta história contestada, na qual a vida privada moderna e o indivíduo moderno se mesclaram na Índia colonial.

\section{IV}

O que apresentarei em seguida é o esboço, por assim dizer, de um capítulo da história da vida doméstica burguesa na Bengala colonial. O material - principalmente textos escritos em bengali, entre 1850 e 1920, para ensinar as mulheres esse tema tão vitoriano: a "ciência doméstica" - se refere à classe média hindu de Bengala, a bhadralok ou "gente decente". O regime britânico instituiu na vida indiana a divisão idealista tricotômica sobre a qual descansam as estruturas políticas modernas: o Estado, a sociedade civil e a família (burguesa). Por isto não é surpresa que as ideias relacionadas com a vida doméstica, a privacidade e o individualismo burguês tivessem chegado à Índia por meio do regime britânico. Entretanto, o que quero destacar aqui com o exemplo da bhadralok são certas operações culturais por meio das quais os "indianos" desafiaram e modificaram estas ideias recebidas de tal maneira que puseram em dúvida dois postulados fundamentais que sustentam a ideia de 
"modernidade" - a família nuclear baseada no matrimônio como modelo para a sociedade e a construção secular e histórica do tempo.

Como tem mostrado Meredith Borthwick (1984), Ghulam Murshid (1983) e outros acadêmicos, a ideia europeia setecentista de "civilização" culminou, na Índia do início do século XIX, em uma madura crítica imperialista à vida doméstica indiana-hindu, considerada, então, inferior ao que se tornaram os ideais da vida doméstica burguesa de meados da época vitoriana. ${ }^{16}$ A questão da "condição das mulheres", na Índia do século XIX, era parte desta crítica, assim como as ideias de indivíduo "moderno", "liberdade", "igualdade" e "direitos". Em passagens notáveis por sua combinação de igualitarismo e orientalismo, James Mill, em seu The History of British India (1817), juntava as temática família e nação com a teleologia da "liberdade":

A condição das mulheres é uma das circunstâncias mais notáveis nos costumes das nações [...]. A história das nações incultas representa uniformemente as mulheres em um estado de abjeta escravidão, da qual emergem lentamente na medida que a civilização avança [...]. À medida em que a sociedade se refina com o desfrute de suas conquistas [...] a condição do sexo débil pouco a pouco melhora, até que se associa em condições de igualdade com o homem e ocupa o lugar de auxiliar voluntário e útil. Um estado de dependência mais estrito e humilhante que este está estipulado para o sexo débil, entre os hindus dificilmente pode ser concebido (MILL, 1840, p. 309-310).

Como é bem conhecido, em geral as classes médias da Índia sentem uma responsabilidade nesta acusação. Do início do século XIX em diante, se desenvolveu em Bengala (e em outras regiões) um movimento para reformar as "condições das mulheres" e para lhes dar uma educação formal. Grande parte deste discurso sobre a educação das mulheres era emancipacionista, na medida que falava a linguagem da "liberdade", da "igualdade" e do "despertar", e recebia a forte influência dos ideais ruskinianos e da idealização da vida doméstica burguesa (BORTHWICK, 1984).

Se alguém vê esta história como parte da história do indivíduo moderno na Índia, então temos aí o surgimento de uma característica interessante. É que nesta literatura sobre a educação das mulheres, certos termos, no final das contas, eram mais discutidos acaloradamente do que outros. Por exemplo, havia um grau de consenso sobre a conveniência da "disciplina" e da "higiene" doméstica como práticas que refletiam um estado moderno, mas a palavra liberdade, sendo um outro termo importante da retórica do moderno, apenas funcionava como indicador de tal consenso social. A palavra era discutida apaixonadamente e nos equivocaríamos se acreditássemos que as paixões refletiam uma simples e aberta batalha entre os sexos. A dita palavra ficou assimilada à necessidade nacionalista de construir fronteiras culturais que, supostamente, separavam o "europeu" do "indiano". A disputa em torno desta palavra, assim, foi central para as estratégias discursivas, pelas quais se criou uma posição de sujeito que permitia ao "indiano" falar. É esta posição de sujeito que quero examinar aqui com mais detalhe.

${ }^{16}$ Sobre a história da palavra civilização, ver Febvre (1973). Devo esta referência à Peter Sahlins. 
O que a literatura bengali sobre a educação das mulheres encenava era uma batalha entre a construção nacionalista de uma norma cultural da família patriarcal, patrilocal, patrilinear e estendida, e o ideal de uma família patriarcal, burguesa e nuclear que estava implícito no discurso europeuimperialista-universalista sobre as "liberdades" do individualismo, da cidadania e da sociedade civil. ${ }^{17}$ Os temas da "disciplina" e da "ordem" eram pontos críticos na hora de dar forma às fantasias nacionalistas da arte e do poder. A “disciplina” era vista como a chave do poder do Estado colonial (quer dizer, moderno), mas requeria certos procedimentos para redefinir o eu. Dizia-se que os britânicos eram poderosos porque eram disciplinados, ordeiros e pontuais em tudo e em cada um dos detalhes de suas vidas e isto era possível devido à educação de "suas" mulheres, sob as quais aportavam o valor e as virtudes da disciplina. A partir daí, a família “indiana”, uma construção colonial, ficava mal pontuada nos escritos nacionalistas sobre a vida doméstica moderna. Para citar um texto bengali anônimo, sobre a educação das mulheres, publicado em 1877:

O lar de qualquer europeu civilizado é com a morada dos deuses. Cada objeto da
casa está limpo, disposto em seu lugar e decorado; nada parece sujo ou fede [...]. É
como se [a deusa] da ordem [srinkhala, "ordem, disciplina"; srinkhal, "cadeia”] tivesse
manifestado para se comprazer a vista [dos homens]. No centro da habitação haverá
uma mesa com toalha e com um ramo de flores acima, enquanto ao seu redor
haverá [algumas] cadeiras acomodadas com esmero [e] tudo brilhando de tanta
limpeza. Mas entre em uma casa de nosso país e sentirá como se seu destino tivesse
te transportado para lá para pagar por todos os pecados de sua vida. [Um monte de]
esterco que tortura os sentidos [...] pó voando no ar, cinzas acumuladas por aí,
moscas voando por toda parte [...], uma criança melequenta urinando no solo e
levando a terra úmida à boca [...]. Todo o lugar está dominado pelo fedor que
parece andar solto por toda parte [...]. Não há ordem em nenhum lado, todos os
objetos da casa estão tão sujos que só provocam asco (STREESIKSHA, 1877, p.
28-29).

Esta divisão do eu do sujeito colonial, o movimento duplo de reconhecimento pelo qual conhece seu "presente" como o lugar da desordem e, não obstante, também se separa deste espaço ao desejar uma disciplina que só pode existir em um futuro imaginado, mas histórico, é uma repetição no contexto da discussão da vida doméstica burguesa na Índia colonial, da narração da transição que temos visto. Em outras palavras, uma construção histórica da temporalidade (medieval-moderna, separadas pelo tempo) é precisamente o eixo sobre o qual o sujeito colonial se separa de si mesmo. Falando de outra forma, esta separação é a própria história; a escrita da história executa tal separação sem cessar.

O desejo da ordem e da disciplina na esfera doméstica pode ser visto, assim, como um correlato do desejo nacionalista, modernizador, de uma disciplina similar na esfera pública, ou seja, como um respeito à lei estabelecida pelo Estado. Aprofundar neste ponto ultrapassa os limites deste ensaio, mas a conexão entre a disciplina pessoal e a disciplina na vida pública foi revelado no que os nacionalistas escreveram sobre a higiene doméstica e a saúde pública. A conexão é reconhecivelmente

\footnotetext{
${ }^{17} \mathrm{O}$ texto clássico a parir do qual essa suposição tem sido explorada até se converter em uma filosofia é Philosophy of Right de Hegel (1967, p. 110-122). Cf., também, Hodge (1987, p. 127-158), During (1988), Ryan (1990).
} 
modernizadora e é o que o indiano moderno compartilha com o europeu moderno. ${ }^{18}$ Entretanto, o que quero ressaltar são as diferenças entre ambos. E passo agora ao outro importante aspecto do europeu moderno, a retórica da "liberdade" e da "igualdade".

O argumento sobre a "liberdade" - nos textos que vamos tratar - era discutido em torno da questão dos ideais vitorianos do matrimônio como sociedade (companionate ${ }^{19}$ ), quer dizer, em volta da indagação sobre se a esposa deveria ser ou não uma amiga do esposo. Nada ameaçava mais o ideal da família estendida bengali-indiana (ou a exaltada posição da sogra nessa estrutura) que esta ideia envolta de noções da vida privada burguesa, segundo as quais a esposa também deveria ser uma amiga, ou, para dizer de outro modo, a mulher deveria ser, agora, um indivíduo moderno. Devo mencionar aqui que o indivíduo moderno, que afirma sua individualidade acima dos reclames da família conjunta ou estendida, quase sempre aparece na literatura bengali do final do século XIX e do início do XX como uma figura inquietada por problemas, amiúde tema de zombaria e desprezo, na mesma narrativa e ensaística bengali que exaltava as virtudes da disciplina e da racionalidade científica na vida pessoal e pública. Esta ironia tinha muitas expressões.

O personagem literário bengali mais conhecido que representa esta censura moral da individualidade moderna é Nimchand Datta, na obra teatral Sadhabar ekadashi (1866), de Dinabandhu Mitra. Nimchand, que recebia educação inglesa, faz citações de Shakespeare, Milton ou Locke na menor oportunidade, usa sua educação com arrogância para ignorar seus deveres para com a família estendida, e expõe sua indignação com o mundo, por meio do álcool e da luxúria. Esta relação metonímica entre o amor à educação "moderna" inglesa (que simbolizava o indivíduo romântico na Bengala oitocentista) e o escorregadio caminho do alcoolismo é sugerida, na obra, na narrativa de uma conversa entre Nimchand e um funcionário bengali da burocracia colonial, um delegado magistrado. $\mathrm{O}$ soberbo, arrogante de seu domínio do inglês, não tarda em derivar para o tema das copas (cujo desconhecimento é sinônimo, para a cultura da classe média bengali da época, de decadência absoluta):

Leio inglês, escrevo inglês, echpechifico em inglês, penso em inglês, sonho em inglês note-se que não são criancices - agora me diga, meu bom amigo, o que gostaria de tomar? - Rosé para as damas, Porto para os cavalheiros e Conhaque para os heróis (MITRA, 1981, p. 138).

Uma conexão similar entre o indivíduo moderno, "livre", e o egoísmo também se fazia presente na literatura sobre educação feminina. A construção era descaradamente nacionalista (e patriarcal). A liberdade era usada para marcar uma diferença entre aquele que era "indiano" e o que era "europeu-inglês". A mulher ultralivre se comportava como uma memsabib (mulher européia), egoísta e desenvergonhada. Como disse Kundamala Devi, uma mulher que escrevia para a revista feminina Bamabodhini patrika, em 1870: "Oh, minhas queridas! Se temos alcançado o verdadeiro conhecimento, então não dêem lugar em seus corações para o comportamento da memsabib. Isto não é próprio de uma

\footnotetext{
${ }^{18}$ Desenvolvo este argumento de forma mais detalhada em Chakrabarty (1991).

${ }^{19}$ Termo que designa a qualidade de companheiro. Casamento realizado entre pessoas que são amigas (N.T.).
} 
ama da casa bengali" (BORTHWICK, 1984, p. 105). A ideia da "verdadeira modéstia" era utilizada para compor esta imagem da "verdadeira" mulher bengali. Em 1920, Indira Devi dedicou seu Narir ukti (Uma mulher fala) - curiosamente, uma defesa do modo de ser da mulher bengali moderna contra as críticas de escritores (em sua maior parte, homens) - às gerações de mulheres bengali ideais, sobre as quais escreve: "Impávidas ante a natureza, de plácidas palavras, incansáveis em seu espírito de serviço [aos demais], negligentes até em seus próprios prazeres, [enquanto que] se comoviam com facilidade pelo sofrimento dos demais, e capaz de contentar-se com muito pouco" (DEVI, 1920, dedicatória).

Esse modelo da mulher bengali/indiana "moderna" - suficientemente educada para apreciar as modernas regras do corpo e do Estado, mas suficientemente "modesta" para ser submissa e desprendida - estava ligado aos debates acerca da "liberdade". A "liberdade" no Ocidente, segundo justificavam vários escritores, significava jathechahachar, fazer o que um queria, direito à autocomplacência. Dizia-se na Índia que liberdade significava estar livre do ego, era a capacidade de servir e obedecer voluntariamente. Note-se como os termos liberdade e escravidão mudam de sentido na seguinte citação:

Poder se subordinar aos demais e ao dharma [dever-ordem moral-conduta correta] [...] para libertar a alma da escravidão dos sentidos são as primeiras tarefas da liberdade humana [...]. É por isto que nas família indianas os meninos e as meninas se subordinam aos pais, as esposas aos maridos e aos sogros, o discípulo ao guru, o estudante ao professor [...], o rei ao dharma [...], o povo ao rei, e a dignidade e prestígio [próprios] à comunidade [sama] (BANDYOPADHYAYA, 1887, p. 30-31) ${ }^{20}$

Há um viés irônico nesta teoria que deve ser destacado. Fica bastante claro que a teoria da "liberdade na obediência" não se estendia aos empregados domésticos, que amiúde eram mencionados nesta literatura como exemplo dos "verdadeiramente" não livres; os nacionalistas pretendiam demonstrar que os observadores (europeus), que comentavam a condição não livre das mulheres indianas, com frequência não conseguiam apreciar esta distinção crucial (ressaltada por alguns nacionalistas) entre a ama de casa e o serviço doméstico. É óbvio que os empregados não estavam incluídos, ainda, na imaginação nacionalista da Índia. Assim rezava o discurso acerca da vida doméstica moderna em uma época colonial, na qual o surgimento de uma sociedade civil e de um Estado quase moderno já tinha introduzido as modernas questões do "público" e do "privado" nas vidas da classe média bengali. As idées rẹcues ${ }^{21}$ burguesas sobre a vida doméstica e as conexões entre o doméstico e o nacional se modificaram de duas maneiras significativas. Uma estratégia, como tenho tentado demonstrar, era contrapor a norma cultural da família estendida patriarcal aos ideais burgueses patriarcais do matrimônio como sociedade, ou se opor ao novo patriarcado com uma versão redefinida do anterior (ou dos anteriores). Assim se combatia a ideia da privacidade moderna. A outra estratégia, igualmente significativa, era mobilizar, em nome da família estendida, as formas e figurações da memória coletiva que desafiavam, mesmo que de maneira ambígua, a separação aparentemente

\footnotetext{
20 Para uma genealogia dos termos escravidão e liberdade no discurso colonial da Índia Britânica, ver Prakash (1990a).

${ }^{21}$ Termo usual no francês que representa uma opinião entre o estereótipo, o clichê e a banalidade. Pode ser, também, assimilado à ideia de crença ou sabedoria popular (N.T.).
} 
absoluta entre tempo "sagrado" e "secular". sobre a qual se baseava e se baseia a própria ideia moderna (“europeia”) de história (BURKE, 1970).

A figura da mulher "verdadeiramente educada", "verdadeiramente modesta" e "verdadeiramente indiana" adquire, nesta discussão, uma autoridade sagrada ao subordinar a questão da vida doméstica às ideias religiosas da qualidade auspiciosa da mulher que unia o celestial ao humano em uma conceitualização do tempo que só podia ser anti-histórica. Dizia-se que a ama de casa verdadeiramente moderna seria tão auspiciosa que marcaria o eterno retorno do princípio cósmico encarnado na deusa Lakshmi, a deusa do bem-estar doméstico, em cujas graças a família estendida (e o clã e, até mesmo, com o prolongamento deste sentir, a nação, Bharatlakshmi vivia e prosperava. Assim lemos em uma panfleto: "As mulheres são as Lakshimis da comunidade. Se se empenham em se superar na esfera do dharma e do conhecimento [...] haverá uma melhoria automática da [qualidade de] vida social" (apud BIKSHUK, 1876, p. 77). Lakshmi, considerada como esposa do deus hindu Vishnu até o ano 400 d.C., é adorada no hinduísmo popular, no panteísmo cotidiano das famílias hindus, como o modelo da esposa hindu, unida em completa harmonia com seu esposo (e com sua família) mediante atitudes de submissão, lealdade, devoção e castidade voluntária. ${ }^{22}$ Quando a mulher não era coerente com seus ideais, dizia-se que a família (estendida) e a linhagem familiar eram destruídas pelo espírito de Alakshmi (não-Lakshmi), o inverso obscuro e malévolo do princípio de Lakshmi. Enquanto a educação das mulheres e a ideia da disciplina raras vezes suscitavam oposições no discurso sobre o indivíduo moderno na Bengala colonial, havia um limite no ponto em que a modernidade e a exigência de uma vida burguesa ameaçavam o poder e o prazer da família estendida.

Não há dúvida de que o sujeito falante aqui é nacionalista e patriarcal, sujeito que emprega as degastadas categorias de "Oriente" e "Ocidente". ${ }^{23}$ Entretanto, o que importa para nós são as duas negações, sob as quais descansa este momento particular de subjetividade: a negação, ou ao menos contestação, da vida privada burguesa e, com igual importância, a negação do tempo histórico, ao converter a família no lugar onde o sagrado e o secular se fundiam, em uma representação perpétua de um princípio celestial e divino.

De forma nenhuma o espaço cultural invocado por este impulso anti-histórico era harmonioso ou estava livre de conflitos, mesmo quando o pensamento nacionalista se via obrigado a retratá-lo assim. As normas anti-históricas da família estendida patriarcal, por exemplo, só poderiam ter a existência debatida, contestada, pela luta das mulheres ou pelas lutas das classes subalternas. Mas estas lutas não necessariamente seguem linhas que permitem construir narrações de emancipação que colocam, claramente, de um lado os "patriarcais" e do outro os "liberais". A história da individualidade "indiana" moderna fica presa em demasiadas contradições para se prestar a semelhante tratamento.

\footnotetext{
22 Cf. Kinsley (1988, p. 19-31), Basu (1873, p. 60), Bhattacharya, (1951, p. 469-471), Dhal (1978). A expressão panteísmo cotidiano me foi sugerida por Spivak (comunicação pessoal).

${ }^{23}$ Cf, em Chatterjee (1986), o capítulo dedicado a Bankim.
} 
Sem espaço para desenvolver esse ponto, me conformarei com um exemplo. Este exemplo tomarei da autobiografia de Ramabai Ranade, esposa do famoso reformista social do século XIX, que chegou à presidência de Bombay, M. G. Renade. A luta de Ramabai Ranade para salvar o respeito por si mesma era, em parte, uma luta contra a "velha" ordem patriarcal da família estendida e em favor do "novo" patriarcado do matrimônio em sociedade, que seu esposo, de ânimos reformistas, via como a forma de laço conjugal mais civilizada. Na busca deste ideal, Ramabai começou a compartilhar o compromisso de seu esposo com a vida pública e, amiúde, passou a tomar parte (na década de 1880) de reuniões e deliberações públicas de homens e mulheres reformistas. Como ela mesmo disse, "foi nestas reuniões que soube o que era uma reunião e como devia me conduzir em uma delas" (RANADE, 1963, p. 77). Contudo, curiosamente, uma das principais fontes de oposição aos esforços de Ramabai vinha (além dos homens) das demais mulheres de família. Não há dúvida de que a sogra e as irmãs de seu esposo falavam em nome da antiga família estendida patriarcal. Mas é muito instrutivo escutar suas vozes (como se revelam no texto de Ramabai), pois elas também falavam de respeito a si mesmas e das suas próprias formas de luta contra os homens:

Não deverias ir a essas reuniões, de verdade [disseram a Ramabai] [...]. Inclusive se os homens querem que faça estas coisas, deverias ignorá-los. Não tens que dizer não: mas, no final de contas, não precisa fazê-lo. Se darão por vencidos por puro aborrecimento [...]. Já estás fazendo mais do que as mulheres europeias, inclusive.

Ou isto:

É ela mesmo [a Ramabai] que gosta desta frivolidade de acudir às reuniões. Dada [o senhor Ranade] não parece tão entusiasmado. $\mathrm{Na}$ verdade, as mulheres não deveriam sentir a proporção do quanto devem fazer? Se os homens mandam fazer cem coisas, as mulheres deveriam fazer dez ao todo. E, depois, os homens não entendem de coisas práticas! [...] A boa mulher [no passado] nunca era tão frívola [...]. É por isto que esta enorme família [...] poderia viver junta de maneira decente [...]. Mas agora tudo é tão diferente! Si Dada sugere uma coisa, esta mulher quer fazer três. Como podemos viver então com um sentido de respeito à nós mesmas e como podemos aguentar tudo isto? (RANADE, 1963, p. 84-85)

Essas vozes, ao combinar os temas contraditórios do nacionalismo, da ideologia do clã patriarcal, das lutas das mulheres contra os homens e, ao mesmo tempo, se opor à amizade entre marido e esposa, nos lembram as profundas ambivalências que caracterizaram a trajetória da vida privada moderna e da individualidade burguesa na Índia colonial. Não obstante, os historiadores, mediante manobras que lembram o velho ardil "dialético" tirado da manga da "negação da negação", as arrumam para negar uma posição de sujeito a essa voz de ambivalência. A evidência do que se tem chamado "a negação da vida privada burguesa e do sujeito histórico" é reconhecida, mas é subordinada, em seus relatos, com o propósito, supostamente mais elevado, de fazer com que a história da Índia seja vista como um episódio da marcha universal e (desde seu ponto de vista, finalmente) vitoriosa da cidadania, do Estado-nação e da emancipação humana, nos termos enunciados no curso da Ilustração europeia. É a figura do cidadão que fala por meio dessas histórias. E, enquanto assim for, 
minha Europa hiperreal continua a dominar nas histórias que contamos. "O moderno", então, continuará sendo entendido, como tão acertadamente disse Meaghan Morris (1990) ao examinar seu próprio contexto australiano, “como uma história conhecida, algo que já tenha sido ocorrido em outra parte e que se reproduzirá, mecanicamente ou de outra forma, com um conteúdo local.” Isto só nos deixa com a tarefa de reproduzir o que Morris chama "o projeto da inoriginalidade positiva"(MORRIS, 1990 , p. 10).

\section{V}

A “originalidade" - aceito que não é o termo mais adequado - das linguagens, mediante as quais têm sido levadas a cabo as lutas no subcontinente indiano, amiúde tem sido reconhecida na esfera do não-moderno. Não é preciso analisar a ideologia do patriarcado clânico, por exemplo, para reconhecer que a metáfora da família estendida patriarcal e santificada foi um dos elementos mais importantes na política cultural do nacionalismo indiano. $\mathrm{Na}$ luta contra o domínio britânico, foi o uso desta linguagem - em canções, poemas e outras formas de mobilização nacionalista - que permitiu aos "indianos" fabricar um sentido de comunidade e recuperar para si mesmos uma posição de sujeito que se dirigia aos britânicos. Ilustrarei isto com um exemplo tomado da vida de Gandhi, "pai da nação", para destacar a importância política desta manobra cultural por parte do "indiano".

Meu exemplo remonta ao ano de 1946. Houve, em Calcutá, horrorosos distúrbios entre hindus e muçulmanos, por conta da partilha do país em Índia e Paquistão. Gandhi estava na cidade, jejuando em protesto contra o comportamento de seu próprio povo. Eis aqui como Amiyia Chakravarty, um intelectual indiano, lembra da experiência:

Os homens voltavam de seus escritórios pela tarde e falavam da comida preparada pela família [ou seja, pelas mulheres] feita para eles; mas prontamente se fazia evidente que as mulheres da casa não haviam comido durante todo o dia. [Aparentemente] não tinham tido fome. Se insistisse, a esposa ou a mãe confessaria que não podia entender como podiam comer quando Gandhi estava morrendo pelos crimes praticados por eles mesmos. Restaurantes e centros de diversão tinham pouca clientela; alguns deles fecharam voluntariamente por ordem de seus proprietários [...]. O valor do sentimento tinha sido restabelecido, começou a se sentir dor [...]. Gandhiji sabia quando começar o processo de redenção (apud PAREKH, 1989, p. 163).

Não há motivos para tomar esta descrição de forma literal, mas a natureza da comunidade imaginada nestas linhas fica clara. Funde, retomando as palavras de Gaytri Spivak (1988, p. 277), “o sentimento de comunidade que pertence aos encadeamentos e às organizações políticas nacionais" com "esse outro sentimento de comunidade cujo modelo estrutural é a família [ou o clã estendido].” A história colonial indiana está cheia de exemplos nos quais os indianos se arrogaram a posição de sujeito, precisamente ao mobilizar, dentro do contexto das instituições "modernas" e às vezes em nome do projeto modernizador do nacionalismo, instrumentos da memória coletiva que eram tão anti- 
históricos como anti-modernos. ${ }^{24}$ Isto não significa negar a capacidade dos "indianos" de atuar como sujeitos armados com aquilo que nós das universidades reconheceríamos como "um sentido da história" (o que Peter Burke chama de "o renascimento do passado") e, sim, insistir que, ao mesmo tempo, coexistiam tendências contrárias e que, nas variadas lutas que tiveram lugar na Índia colonial, as construções anti-históricas do passado proporcionavam formas muito poderosas de memória coletiva. $^{25}$

Assim, existe este duplo vínculo, por meio do qual o sujeito da história "indiana" articula a si mesmo. Ele é, ao mesmo tempo, o sujeito e o objeto da modernidade, já que simboliza uma suposta unidade chamada "o povo indiano", que sempre está dividido em duas: uma elite modernizadora e um campesinato por modernizar. Como sujeito dividido, ele fala do interior de uma meta-narração que celebra o Estado-nação; e desta meta-narração o sujeito teórico só pode ser uma "Europa" hiperreal, uma "Europa" construída pelos relatos que, tanto o imperialismo como o nacionalismo, têm contado aos colonizados. O estilo da autorrepresentação que o "indiano" pode adotar aqui é o que Homi Bhabha tem chamado, com justeza, de estilo "mimético" (BHABBA, 1987, p. 317-326). ${ }^{26}$ A história indiana, inclusive aquela escrita pelos punhos dos escritores socialistas ou nacionalistas mais dedicados, continua sendo uma imitação de um certo sujeito "moderno" da história "europeia" e preserva, em alguns aspectos, a busca por representar uma lamentável figura de carência e fracasso. A narração da transição continuará, sempre, sendo "onerosamente incompleta".

Por outro lado, as manobras são levadas a cabo dentro do espaço do "mimético" - e dentro do projeto chamado história "indiana" - para representar a "diferença" e a "originalidade" do "indiano"; e é por esta causa que os discursos se apropriam dos instrumentos anti-históricos da memória e das "histórias" anti-históricas das classes subalternas. Assim, as construções dos campesinos-trabalhadores de reinos "míticos" e de passados e futuros "míticos" encontram um lugar nos textos denominados como história "indiana", precisamente por meio de um procedimento que subordina estas narrações às regras da evidência e ao calendário secular, linear, que a escrita da "história" deve seguir. Por isto, o sujeito anti-histórico, anti-moderno, não pode falar como "teoria" dentro dos procedimentos de conhecimento da universidade, inclusive quando estes procedimentos de conhecimento reconhecem e "documentam" sua existência. De forma muito parecida à categoria do "subalterno" de Spivak (ou o campesino do antropólogo, que só pode ter sua existência citada em um enunciado mais amplo, pertencente ao próprio antropólogo), por este sujeito e deste sujeito só pode falar a narração de transição que sempre acabará por privilegiar o moderno, quer dizer, a "Europa” (SPIVAK, 1990).

Enquanto continuar operando dentro do discurso da "história" produzido no espaço institucional da universidade será impossível se distanciar do conluio profundo entre a "história" e a (as) narração (narrações) da cidadania, da vida pública e privada burguesa e do Estado-nação. A

\footnotetext{
${ }^{24}$ Cf. Arnold e Hardiman (1982-1992). Ver, também, Nandy (1983).

${ }^{25}$ Cf. Arnold e Hardiman (1982-1992) e Guha (1983)

${ }^{26}$ Em português, BHABHA, Homi K. Da mímica e do homem: a ambivalência do Discurso Colonail. In: O local da cultura. Belo Horizonte: Ed. UFMG, 1998, p. 129-138 (N.T.)]. Ver, também, Bhabha (1990).
} 
"história", como sistema de conhecimento, está firmemente embutida nas práticas institucionais que, a cada passo, invocam o Estado-nação - veja, por exemplo, a organização e a política de ensino, seleção, promoção e publicação nos departamentos de história, políticas que sobrevivem às ocasionais tentativas, valorosas e heroicas, de historiadores individuais de libertar a "história" da meta-narração do Estado-nação. Então é preciso perguntar: por que, hoje, a história é uma matéria obrigatória da educação da pessoa moderna em todos os países, incluindo aqueles que, comodamente, viveram sem ela até tardiamente, no fim do século XVIII? Por que as crianças de todo o mudo, hoje em dia, devem lidar com uma assinatura chamada "história", quando sabemos que esta obrigatoriedade não é nem natural nem antiga?27 Não é preciso muita imaginação para perceber que a razão disto está no que o imperialismo europeu e os nacionalismos terceiro-mundistas têm feito juntos: a universalização do Estado-nação como a forma mais conveniente de comunidade política. Os Estados-nações têm capacidade para fazer cumprir seus jogos de verdade, e as universidades, apesar de sua distância crítica, são parte do conjunto de instituições cúmplices deste processo. A "economia" e a "história" são as formas de conhecimento que correspondem às duas instituições mais importantes que o surgimento (e, mais tarde. universalização) da ordem burguesa legou ao mundo: o modo de produção capitalista e o Estado-nação (no qual a "história" fala à figura do cidadão). ${ }^{28}$ Um historiador crítico não tem maiores opções, a não ser negociar este conhecimento. Ela ou ele precisa entender o Estado em seus próprios termos, quer dizer, em termos de suas narrações autojustificantes da cidadania e da modernidade. Como estes temas sempre nos farão voltar às proposições universalistas da filosofia política "moderna" (europeia) - inclusive a ciência "prática" da economia, que agora parece "natural" para a construção dos sistemas mundiais, está (teoricamente) enraizada nas ideias de ética da Europa do século XVIII $($ SEN, 1987)29 -, um historiador terceiromundista está condenado a conhecer a "Europa" como o lar original do "moderno", enquanto que o historiador "europeu" não compartilha uma dilema semelhante sobre os passados da maior parte da humanidade. Assim, a subalternidade cotidiana das histórias não-ocidentais, com a qual comecei estas linhas, continua.

Contudo, a compreensão de que todos "nós" fazemos história "europeia" com nossos arquivos, diferentes e não europeus, dá lugar à possibilidade de uma política e de um projeto de aliança entre as histórias dominantes da metrópole e os passados subalternos periféricos. Chamemos a este projeto de provincialização da "Europa", a "Europa" que o imperialismo moderno e o nacionalismo (terceiromundista), mediante suas agências e violências conjuntas, tornaram universal. Filosoficamente, este projeto deve se fundar em uma crítica radical e transcendente do liberalismo (quer dizer, das construções burocráticas da cidadania, do Estado moderno e da vida privada burguesa que a filosofia clássica produz), princípio compartilhado nos últimos escritos de Marx e, em certos momentos, tanto

\footnotetext{
${ }^{27}$ Sobre a estrita conexão entre as ideologias imperialistas o ensino da história na Índia colonial, ver Guha (1988).

${ }^{28}$ Sem implicações sobre o argumento, existem paralelos entre minha declaração e o que foi dito por Prakash (1990b, p. 383408) e Dirks (1990, p. 25-33).

${ }^{29}$ Morris-Suzuki (1989) também faz uma interessante leitura sobre este aspecto. Agradeço a Gavan McCormack por ter chamado minha atenção para este livro.
} 
no pensamento pós-estruturalista como na filosofia feminista. Em particular, me sinto encorajado pela corajosa declaração de Carole Pateman - em seu livro The Sexual Contract - segundo a qual a concepção do indivíduo moderno pertence às categorias patriarcais do pensamento (PATERNAN, 1988, p. 184).

\section{VI}

O projeto de provincializar a "Europa" se insere em uma história que, entretanto, não existe. Portanto, eu só posso falar disso em uma perspectiva programática. Para evitar um entendimento equivocado, devo falar do que não está explícito, mas que pode vir a ser.

Para começar, não se pede uma recusa simplista, indiscriminada, da modernidade, dos valores liberais, universais, da ciência, da razão, das narrações onímodas, das explicações totais etc. Fredric Jameson recentemente nos fez recordar que a fácil comparação, feita com frequência, entre "uma concepção filosófica de totalidade" e "uma prática política do totalitarismo" é "funesta" (JAMESON, 1988, p. 354). O que intervém entre as duas coisas é a história - lutas contraditórias, plurais e heterogêneas cujos resultados nunca são predisíveis, nem sequer em retrospectiva, de acordo com esquemas que buscam naturalizar e domesticar esta heterogeneidade. Estas lutas incluem a coerção (tanto em nome de como contrária à modernidade), sob a forma de violência física, institucional e simbólica, apesar de administrada com um idealismo sonhador. E é esta violência que tem um papel decisivo no estabelecimento do significado, na criação dos regimes de verdade, ao decidir, por assim dizer, quais são os "universais" e de quem eles ganham. Como intelectuais atuantes na academia, não somos neutros nestas lutas e não podemos pretender nos situar fora dos procedimentos de conhecimento de nossas instituições.

O projeto de provincializar a "Europa", por isto, não pode ser um projeto de "relativismo cultural". Não pode nascer da postura que crê que a razão-ciência-universais, que ajudam a definir a Europa como o moderno, é de natureza cultural específica e pertencente apenas às culturas europeias. Não se trata de mostrar que o racionalismo da Ilustração é irracional em si mesmo, mas sim de documentar como - e mediante quais processos históricos - sua "razão", que nem sempre foi evidente para todos, tem sido apresentada como "óbvia" para além dos terrenos nos quais se originou. Se uma língua, como se diz, não é nada mais do que um dialeto respaldado por um exército, a mesma coisa pode se dizer das narrações da "modernidade", que, atualmente, quase de maneira universal, assinalam uma certa "Europa" como o habitat primário do moderno.

É demonstrável que esta Europa, como o "Ocidente", é uma entidade imaginária, mas a demonstração não diminui seus atrativos ou seu poder. O projeto de provincializar a "Europa" tem que incluir alguns elementos: 1) o reconhecimento de que a atribuição, por parte da Europa, do adjetivo moderno a si própria é uma peça da história global e parte integrante do relato do imperialismo europeu; 2) e a compreensão de que a associação entre uma certa visão da Europa e a "modernidade" não é obra exclusiva dos europeus; os nacionalismos terceiromundistas, como ideologias modernizadoras par excellence, são sócios com partes iguais neste processo. Não pretendo 
negligenciar os momentos anti-imperialistas nas trajetórias destes nacionalismos. Só ressalto que o projeto de provincializar a "Europa" não pode ser um projeto nacionalista, autoctonista ou atavista. Desvendar o inevitável enredo da história - uma forma disciplinada e institucionalmente regulamentada de memória coletiva - com as narrações globais dos "direitos", da "cidadania", do Estado-nação, das esferas "pública" e "privada", pressupõe problematizar a "Índia" e, ao mesmo tempo, desmantelar a "Europa". A ideia é inscrever, na história da modernidade, as ambivalências, contradições, o uso da força, as tragédias e as ironias que a acompanham. É inegável que a retórica e as reivindicações de igualdade (burguesa) de direitos dos cidadãos, assim como da luta por autodeterminação mediante a conquista do Estado-nação soberano, em muitas circunstâncias levam à concessão de poder a grupos sociais marginalizados - este reconhecimento é indispensável para o projeto de Subaltern Studies. Contudo, o que de fato tem importância nas histórias que, implicitamente ou explicitamente, celebram o advento do Estado moderno e da ideia da cidadania é a repressão e a violência, ferramentas tão importantes na vitória do moderno como o poder de convencimento de suas estratégias retóricas. Não existe lugar onde a ironia - o fundamento antidemocráticos da "democracia" - seja mais visível que na história da medicina moderna, da higiene pública e da higiene pessoal, cujos discursos foram centrais na localização do corpo do moderno na interseção entre o público e o privado, tal como definido pelo Estado e sujeito às negociações com ele. Contudo, o triunfo do moderno sempre dependeu da mobilização, em seu nome, de meios efetivos de coerção física. Digo "sempre" porque esta coerção é tanto originária-fundacional (ou seja, histórica) como pandêmica e cotidiana. Da violência fundacional, David Arnold dá um bom exemplo em seu recente ensaio sobre a história do cárcere na Índia. A coerção da prisão colonial, como mostra Arnold, foi contemplada em algumas das primeiras e pioneiras investigações sobre as estatísticas médicas, nutricionistas, e demográficas da Índia, pois era na prisão que os corpos indianos estavam à disposição dos investigadores que promoviam a modernização. Da coação, que continua a ser exercida em nome da nação e da modernidade, tomo um exemplo recente, da campanha indiana de erradicação da varíola, nos anos mil novecentos e setenta. Dois médicos estadunidenses (um deles, presumivelmente, de origem "indiana") que participaram no processo descrevem suas operações em uma aldeia da tribo Ho, no estado indiano de Bihar:

Na metade da serena noite indiana, um intruso irrompeu através da porta de bambu da humilde choça de adobe. Era um vacinador do governo com ordens de combater a resistência à vacina contra a varíola. Lakshmi Singh se despertou gritando e correu como pôde para se esconder. Seu esposo saltou da calam, tomou um machado e botou o intruso para frente da casa. Lá fora havia um esquadrão de médicos e policiais que imediatamente subjugaram Mohan Singh. Logo quando o detiveram no chão, outro vacinador injetou a vacina contra a varíola em seu braço. Mohan Singh, um magro e forte dirigente da tribo Ho, de quarenta anos de idade, retorceu seu braço para tirar a agulha, fazendo com que a picada sangrasse. A quadrilha do governo o sujeitou até que conseguiram injetar suficientemente a vacina [...]. Enquanto dois policiais o repreendiam, o resto da quadrilha submeteu o resto da família e vacinou cada membro, um por um. Lakshmi Singh mordeu com força a 
mão de um dos médicos, mas não adiantou de nada (BRILLIANT; BRILLIANT, 1978 , p. 3). ${ }^{30}$

Não é possível ignorar o idealismo que acompanha a violência. O subtítulo do artigo citado reproduz inconscientemente os instintos, tanto militares como de beneficência, da empresa: "como um exército de samaritanos expulsou a varíola da terra."

As histórias que tratam de deslocar a Europa hiperreal do centro até onde a imaginação histórica gravita atualmente terão de buscar, sem descanso, esta conexão entre a violência e o idealismo, que age no coração do processo no qual as narrações da cidadania e da modernidade encontram um lar-natural na "história". Tenho aqui uma discordância fundamental para com a postura assumida por Richard Rorty, em debate com Jürgen Habermas. Rorty critica Habermas por este ter afirmado que "o relato da filosofia moderna é uma parte importante do relato das tentativas das sociedades democráticas de tranquilizar suas consciências" (RORTY, 1986, p. 169). A declaração de Rorty é coerente com a prática de muitos europeístas, que falam das histórias das "sociedades democráticas" como se fossem histórias autônomas, completas em si mesmas, como se a autoconstrução do Ocidente fosse algo que ocorreu somente dentro das fronteiras geográficas que ele construiu para si mesmo. Por assim dizer, Rorty ignora o papel que o "teatro colonial" (tanto externo como interno) - no qual o tema da "liberdade", tal como definido pela filosofia política moderna, era invocado constantemente em auxílio às ideias de "civilização", "progresso" e, mais tarde, de "desenvolvimento" - tem no processo como elemento gerador dessa "tranquilidade". A tarefa, como se vê, será combater estas ideias que legitimam o Estado moderno e suas instituições para que retorne a filosofia política - da mesma maneira como moedas suspeitas regressam a seus donos em um bazar indiano - com suas categorias, cujo valor global já não pode ser dado como certo. ${ }^{31}$

Por último - como a "Europa", depois de tudo, não pode ser provincializada dentro do espaço institucional da universidade, cujos protocolos de conhecimento sempre nos levaram de volta ao terreno onde todos os contornos seguem os de minha Europa hiperreal -, o projeto de provincializar a Europa deve ser realizado dentro de sua própria impossibilidade. Este projeto contempla uma história que encarna esta política da desesperança. E deve ficar claro, neste ponto, que não peço um relativismo cultural ou histórias atavísticas, nativistas. Tampouco se trata de um programa para uma simples recusa da modernidade, o que seria, em muitas situações, um suicídio político. Peço uma história que, deliberadamente, torne visível, dentro da mesma estrutura de suas formas narrativas, as estratégias e práticas de repressão, bem como o papel que exerce, em conluio com as narrações de cidadania, ao se assimilar aos projetos do Estado moderno, colocando-o acima de todas as demais possibilidades de solidariedade humana. A política da desesperança precisará de uma história que esclareça aos seus leitores as razões pelas quais semelhante categoria é necessariamente ineludível. Trata-se de uma história que tentará o impossível: olhar até sua própria morte para rastrear aquilo que resiste e escapa

\footnotetext{
${ }^{30}$ Devo esta referência a Paul Greenough.

31 Para uma leitura interessante e que revisa Hegel, ver o debate entre Taylor (1990) e Chatterjee (1990) em Public Culture 3, número 1 (1990). Meu livro Retbinking Working-Class History tenta abrir uma brecha nesta direção (CHAKRABARTY, 1989)
} 
ao melhor esforço humano de tradução, por meio de sistemas culturais ou de outro tipo de sistemas semióticos, para que o mundo possa, uma vez mais, ser imaginado como profundamente heterogêneo. Isto, como tenho afirmado, é impossível dentro dos protocolos de conhecimento da história acadêmica, pois a globalidade do mundo acadêmico não é independente da globalidade que a categoria europeia do moderno tem criado. Tentar provincializar essa "Europa" é ver o moderno como inevitavelmente contestado, é escrever em cima das narrações dadas e privilegiadas da cidadania outras narrações das conexões humanas, que se alimentam dos passados e dos futuros sonhados, nos quais as coletividades não se definem pelos rituais da cidadania nem pelo pesadelo da "tradição" inventada da "modernidade". Desde já, afirmo que não existe espaço (infra)estrutural no qual tais sonhos podem habitar. Apesar disto, estes sonhos se repetirão enquanto os temas da cidadania e do Estado-nação continuarem dominando nossas narrações da transição histórica, pois estes sonhos são o que o moderno reprime para poder existir.

\section{REFERÊNCIAS}

ARNOLD, D.; HARDIMAN, D.. Subaltern Studies, v. 1-7, Delhi: Oxford University Press, 1982-1992.

BANDYOPADHYAYA, D. Nanabishayak prabandha. Calcuta, 1887.

BASU, M. Hindu acar byabahar. Calcuta, 1873.

BAUDRILLARD, J. Simulations. Nueva York: Semiotext[e], 1983.

BENNETT, D. Postmodernism and Vision: Ways of Seeing (at) the End of History. In: D'HAEN, Theo. Postmodern Studies, 3: History and Post-War Writing. Amsterdam: Rodopi, 1990. p. 259-279.

BHABHA, Homi (ed.). Nation and Narration. London: Routledge, 1990.

BHABHA, Homi. Of Mimicry and Man: The Ambivalence of Colonial Discourse. In: MICHELSON. A. et al (ed.). October, v. 28. Cambridge., 1987. p. 317-326.

BHATTACHARYA, H. D. Minor Religious Sects. In: MAJUMDAR,R. C. (ed.). The History and Culture of the Indian People, v. 2.: The Age of Imperial Unity, Bombay: Bharatiya Vidya Bhavan 1951. p. 463475.

BIKSHUK [Chandrasekhar Sen]. Ki holo!, Calcuta, 1876.

BORTHWICK, M. The Changing Role of Women in Bengal, 1849-1905. Princeton, N. J: Princeton University Press, 1984.

BRILLIANT, L.; BRILLIANT, G. Death for a Killer Disease. Quest, p. 3-10, May-June 1978.

BURKE, P. The Renaissance Sense of the Past. Londres: St Martin's Press, 1970.

CHAKRABART, D. Open Space/Public Place: Garbage, Modernity, and India. South Asia, v. 4, p. 15-31, 1991. 
CHAKRABARTY, D. Rethinking Working-Class History: Bengal, 1890-1940; Princeton: Princeton University Press, 1989.

CHAKRABARTY, D. Sarir, samaj, o rashtra: Oupanibeshik bharate mahamari o janasangskriti. Anustup, 1988.

CHATTERJEE, P. A response to Taylor's "Modes of Civil Society". Public Culture, v. 3, n. 1, p. 119132, 1990.

CHATTERJEE, P. Nationalist Thought and the Colonial World: A Derivative Discourse? Londres: Zed Books, 1986.

CHAUDHURI, N. C. The Autobiography of an Unknown Indian. Nueva York: University of California Press, 1989.

CHAUDHURI, N. C. Thy Hand, Great Anarch!: India, 1921-1952. Londres: Chatto \& Windus. 1987.

CONNOLLY, W. E. Political Theory and Modernity. Oxford, 1989.

DAVIS, N. Z. Boundaries and Sense of Self in Sixteenth-Century France. In: HELLER, T. C.; SOSNA, M. (ed). Reconstructing Individualism: Autonomy, Individuality and the Self in Western Thought. Stanford: Stanford University Press, 1986. p. 53-63.

DAVIS, N. Z. Fame and Secrecy: Leon Modena's Life as an Early Modern Autobiography. History and Theory, v. 27, n. 4, p. 103-118, 1988.

DEVI, I. Narir ukti. Calcuta, 1920

DHAL, U. Goddess Lakshmi: Origin and Development. Delhi: Oriental Publishers \& Distributors. 1978.

DIRKS, N. B. History as a Sign of the Modern. Public Culture, v. 2, n. 2, p. 25-33, 1990.

DOW, A. History of Hindostan. v. 1. Londres, 1812-1816.

DURING, S. Rouseau's Heirs: Primitivism, Romance and Other Relations Between the Modern and the Nonmodern. In LANDES, J. B. Women and the Public Sphere in the Age of the French Revolution. Ithaca: Cornell University Press, 1988.

FEBVRE, L. Civilization: Evolution of a Word and a Group of Ideas. In: BURKE, P. (ed.). A New Kind of History: From the Writings of Febvre. Londres: Routledge and Kegan Paul, 1973. p. 219-257.

GANDHI, M. K. Hind Swaraj (1909). In: GANDHI, M. K. Collected Works of Mahatma Gandhi. v. 10. Publication Division, Ministry of Information and Broadcasting Government of India, 1963.

GUHA, R.. An Indian Historiography of India: A Nineteenth-Century Agenda and Its Implications. Calcuta: Center for Studies in Social Sciences, 1988.

GUHA, Ranajit. Elementary Aspects of Peasant Insurgency. in Colonial India. Delhi: Oxford University Press, 1983.

GUHA, R.; SPIVAK, G. C. (ed.). Selected Sublatern Studies. Nueva York: Oxford University Press, 1988.

HABERMAS, J. The Structural Transfor mation of the Public Sphere: An Inquiry into a Category of Bourgeois Society. Cambridge, Mass: MIT Press, 1989. 
HALBFASS, Wilhelm. India and Europe: An Essay in Understanding. Nueva York: State University of New York Press, 1988.

HEGEL, F. Philosophy of Right. London: Oxford University Press, 1967.

HOBHOUSE, L. T. Liberalism, Nueva York: Oxford University Press, 1964.

HODGE J. Women and the Hegelian State. In: KENNEDY, E.; MENDUS, S. (ed.). Women in Western Philosophy. Brighton: Wheatshef Books, 1987. p. 127-158.

HUSSERL, E. The Crisis of European Sciences and Transcendental Pbilosophy. Evanston: Northwestern University Press, 1970.

HUTCHEON, L. The Politics of Postmodernism. London: Routledge, 1989.

INDEN, R. Orientalist Constructions of India. Modern Asian Studies, v. 20, n. 3, p. 401-446, 1986.

JAMESON, F. Cognitive Mapping. In: NELSON, C.; GROSSBERG, L. (ed.). Marxism and the Interpretation of Culture. Urbana: University Illinois Press, 1988, p. 347-369.

KINSLEY, D. Hindu Goddesses: Visions of the Divine Feminine in the Hindu Religious Tradition, Berkeley: University of California Press, 1988.

LEJEUNE, P. On Autobiography. Minneapolis: University of Minnesota Press, 1989.

MARX, K. Capital: A Critique of Political Economy, v. 3. Moscú, 1971.

MARX, K. Grundrisse: Foundations of the Critique of Political Economy. Harmondsworth, 1973.

MARX, K. On the Jewish Questio en Early Writings, Harmondsworth, 1975.

MILL, J. The History of British India, v. 1. Ed. por H. H. Wilson. Londres, 1840.

MITRA, D. Dinabandhu acanabali. Calcuta: Kshetra Gupta., 1981.

MORRIS, M. Metamorphoses at Sydney Tower. New Formations, v. 11, p. 5-18, 1990.

MORRIS-SUZUKI, T. A History of Japanese Economic Thought. London: Routledge, 1989.

MURSHID, G. Reluctant Debutante: Response of Bengali Women to Modernisation, 1849-1905. Rajshahi, 1983.

NANDY, A. The Intimate Enemy: Loss and Recovery of Self Under Colonialism. Delhi: Oxford University Press, 1983.

PAREKH, B. Gandhi’s Political Discourse, Londres: Palgrave Macmillan, 1989.

PATEMAN, C. The Sexual Contract. Stanford, Calif: Stanford University Press, 1988.

PRAKASH, G. Bonded Histories: Genealogies of Labor Servitude in Colonial India. New York: Cambridge University Press, 1990a.

PRAKASH, G. Writing Post-Orientalist Histories of the Third World: Perspectives from Indian Historiography. Comparative Studies in Society and History, v. 32, n. 2, p. 383-408, abr. 1990 b. 
RANADE, R. His Wife's Reminiscences. Delhi: Publications Division, Ministry of Information and Broadcasting, Government of India, 1963.

RORTY, R. Habermas and Lyotard on Postmodernity. In: BERNSTEIN, Richard J., (ed.) Habermas and Modernity. Cambridge: Cambridge: Massachusetts Institute of Technology Press, 1986. p. 161-175.

RYAN, M. Women, in Public: Between Banners and Ballots, 1825-1880. Baltimore: The Johns Hopkins University Press, 1990.

SARKAR, S. Modern India, 1885-1947. Delhi: Macmillan, 1985a.

SARKAR, S. Social History: Predicament and Possibilities. In: KHAN, I. (ed). Fresh Perspective on India and Pakistan. Essays on Economics, Politics, and Culture, Oxford: Oxford University Press, 1985b. p. 256-274.

SEN, A. K. Of Ethics and Economics. In: A History of Japanese Economic Thought. New Delhi: Oxford University Press, 1987.

SPIVAK, G. C. Can the Subaltern Speak?. In: NELSON, C.; GROSSBERG, L. (ed.). Marxism and the Interpretation of Culture. Urbana: University Illinois Press, 1988. p. 271-313.

SPIVAK. Socialist Review, v. 20, n. 3, p. 81-98, jul.-sep. 1990.

TAYLOR, C. Modes of Civil Society. Public Culture, v. 3, n. 1, 1990, p. 95-118, 1990.

VISVANATHAN, G. Maskes of Conquest. Literary Studies and British Rule in India. Londres, 1989. 
